\title{
Security and development: Role of the Nepali Army in nation building
}

\section{Sonika Adhikari}

\begin{abstract}
This paper aims to highlight the integral role of Nepali Army towards national security and development. The researcher has applied secondary source of research design to collect the information. The result suggested that the Nepali Army played a major role in the formation as well as the development of Nepal as a strong stable nation-state. For the national security, the Nepali Army had fought many battles. Their contribution was visible from the unification campaign initiated by Prithvi Narayan Shah in 1740 AD to the Nepalese Civil war fought between the Communist Party of Nepal and the government of Nepal from 1996 to 2006. Similarly, for the development of the nation, their role is visible in infrastructure development, building civil military relation, disaster management, nature conservation and so on. Nepali Army along with the national security has been expanding its role in sectors like education, health and recreation with the interest of serving the people.
\end{abstract}

Keywords: Nepali Army, national security, development

\section{Introduction}

Constitution of Nepal 2015 defines Nepal as an independent, indivisible, sovereign, secular, inclusive, democratic, socialismoriented, federal democratic republican state. Such a constitution-defined identity of our country today would not have been possible without the contribution of Nepali Army (NA) from the time immemorial. Our constitution further adds that safeguarding of freedom, sovereignty, territorial integrity, nationality, independence and dignity of Nepal, the rights of the Nepalese people, border security, economic wellbeing and prosperity shall be the basic elements of the national interest of Nepal, which has also been the major interest of the Nepali Army.

The Nepali Army lives by its ethos of 'Mission First and People Always'; demonstrates, in its daily activities, its core values of 'Duty, Integrity, Selfless Service, Courage, Discipline and Loyalty; and adheres to the noble Guiding principles of 'Patriotism, Camaraderie, Institutional Cohesiveness, Respect for Diversity and Dignity of Service'. The institutional history of the NA establishes a direct link between modern Nepal and its national territory as invading independent principalities and conquering territories through fortified armed strength was considered a common practice (Nepali Army, 2019). Hence, the Nepali Army has equally supported the transformation and development of Nepal from 'nation formation' to 'nation building'.

\section{Role of Nepali Army in nation building}

The Nepali Army primarily aims at protecting Nepal and ensures national security. The NA has fought many battles against the alien's 
armies and those of the soldiers of small principalities that existed in our country. "The Nepali Army's military history coincides with the country's history, because the rulers used the military as the tool to prolong their regime" (Bhattrai, 2017).

The 1700s was a century of uncertainty throughout the world. The world military powers like Britain, France and Portugal had been rigorously annexing colonies to expand their Empires across the world. Clashes in their interests resulted in wars in different countries and principalities. Britain and France were also moving towards South and Southeast Asia. Such a move also threatened Nepal ever since early decades of the eighteenth century.

The British East India Company commenced its rule in India in 1757 after the Battle of Plassey. It was approaching Nepal while moving towards the Northeast. Nepal was divided into several principalities during this period. At that time, King Prithvi Narayan Shah, hailing from one of the principalities called Gorkha, decided to unify those small kingdoms across Nepal. Although Gorkha was small and economically weak, King Prithvi Narayan Shah amazed the world by undertaking the task of unification of those principalities in complex and difficult circumstances then. The Unification Campaign was initiated in $1740 \mathrm{AD}$ at the time the British had already commenced colonizing the Indian provinces.

This was a turning point in the history of the Nepali Army. Since unification was not possible without a strong army, the management of the armed forces had to be exceptional. Apart from an organized standard army in Gorkha, technicians and experts had to be brought in from abroad to manufacture war materials. After the Gorkhali troops finally captured Kathmandu (then known as Nepal), the Gorkhali armed forces turned into the Nepali Army (Nepali Army, 2019).

Prithvi Narayan Shah would never have been able to continue the expansion campaign without a strong and motivated army. A series of battles of Nuwakot and that of Kirtipur made significant contributions towards the unification of Nepal. Similarly, the battle of Makwanpur (1762-63), Hariharpur Gadhi, military operations of Mirkasim's force (January 1763), the battle of Sindhuli, Kangra Fort, a series of battles of Nalapani, the battle of Jaithak, Deuthal, Jitgadh, and so on, cannot even be imagined without brave Nepali soldiers(Rayamajhi, 2019). "According to Stiller, the story of Nepal's growth as a nation spans the year from 1744 to 1951 . Historian John Whelpton, in his book Kings, Soldiers and Priests, writes that Prithvi Narayan Shah conquered Kathmandu with support of Nepali Army in 1769" (Poudel, 2016).

The role of the Nepali Army was also evident during the ten-year Maoist Insurgency. Such an internal conflict between the Communist Party of Nepal (CPN-Maoist) and the Government of Nepal from 1996 to 2006 had almost crippled the country on different fronts. On 13 February 1996, the CPN had initiated the rebellion with a stated purpose of overthrowing the Nepalese monarchy and establishing a People's Republic. It ended with the signing of the Comprehensive Peace Accord on 21 November 2006. During the clash, the Nepali Army was mobilized to pressure insurgents to come to negotiations with the establishment and the government of Nepal. The Nepalese monarchy has always relied on the military to consolidate its power both against growing popular opposition and during violent uprisings (Dhungana, 2007). 
Hence, the Nepali Army continued to march with Prithvi Narayan Shah's quest of building a Hindu nation from 1743 to 1816 when Nepal signed Sugauli Treaty with the British India. As Nepal turned from a monarchy to a republic and from a unitary to federal setup, the Nepali Army has remained the sole institution to defend the national unity, social integrity and people's sovereignty. Even after the promulgation of the new constitution in September 2015, the Nepali Army has been consistently discharging its primary duties and obligations to the leadership and institution even in the fragile situation of Nepal.

Nepal lies in an area that is at a high risk from natural calamities. On several occasions, the Nepali Army, in response to several natural and manmade disasters, has mobilized its well-trained and highly skilled personnel in rescue missions and saved thousands of lives and property (Nepalese Army, n.d). In building a nation from building infrastructures like roads to providing education and health, the Nepali Army has been serving the people at all times, not just in times of natural disasters. The areas promoted by the Nepali Army beyond primary duties involve the following areas:

\section{Infrastructure development}

The Nepali Army has constructed a number of roads and highways, including those of strategic importance for the country. NA has constructed more than 1030 kilometers of road in different parts of the country, particularly linking north-south remote parts of Nepal to the rest of the country. In addition, almost 600 kilometers of road is under construction. These roads include:

The Nepali Army was the major partner in the old Kantipath project linking
Kathmandu to the Indian border with $105 \mathrm{~km}$ road.

It also constructed the Kharipati Nagarkot road.

North West of Kathmandu, the Trishuli - Somdang road cuts through $105 \mathrm{kms}$ of extremely difficult terrain completed in 1990.

> By developing the $88 \mathrm{~km}$ long KatariOkhaldhunga road, the Everest region got necessities of life delivered right at their doorsteps with its completion in 2005.

> It also constructed $28 \mathrm{~km}$ long HileLeghuwaghat for the country.

> The 86 km long Salyan-Musikot road runs through some of the most remote and deprived parts of Nepal completed in 2005.

> The $232 \mathrm{~km}$ long Surkhet - Jumla road, built in large parts by the NA, signaled as one of the Herculean development achievements in modern Nepal.

$>$ The Baglung-Beni-Jomsom road, 91 $\mathrm{km}$ long, provides transport to a region rich in agriculture products.

> The $45 \mathrm{~km}$ long Drabya Shah Marga, built with a view to combat insurgency through development and security simultaneously.

> The Besi Sahar-Chaame road, 65 $\mathrm{km}$ long mountainous road provides service support to one of the most popular tourism areas in Nepal.

Several roads, including the 107 km Chhinchu-Jajarkot, the $112 \mathrm{~km}$ Jajarkot-Dolpa, the $31 \mathrm{~km}$ DevsthalChourjahari, the $145 \mathrm{Km}$ MusikotBurtibang, the $91 \mathrm{~km}$ NagmaGamgadhi are currently under construction to provide access to some 
of the remote and least developed areas of Nepal.

Likewise, the $81.8 \mathrm{~km}$ Nijgadh Kathmandu fast track is currently under construction which considered an important catalyst in the connection of the Terai and the capital city Kathmandu (Nepali Army, 2019).

\section{Civil military relations}

Construction of development infrastructures, disaster management and preservation of nature are parts of the military work under civil-military relations. NA has also contributed significantly to the country and community through the provision of specific capabilities, such as engineers, medical teams and Special Forces contingents. The NA personnel's duty and excellent performances have been widely acclaimed. "People First and Mission Always", a conceptual thinking and it aims towards creating, A Learning, Agile and Effective Organization" (Thapa, 2019).

On 6 Poush 2076, the NA launched public awareness programs on nature conservation to the students and teachers of Solukhumbu. Similarly, it organized another awareness campaign for the cold affected people in Nawalparasi district. Then, it launched a free health camp for the privileged and locals of Bharatpur on 8 and 9 of Poush. Next, the intensive mobile health camp jointly organized by the NA and the Ministry of Health resulted in 34,172 beneficiaries, including 329 surgeries.

The Nepali Army has been utilizing its trained manpower and rich resources in support to Nepal's missions of peace, progress and prosperity for many decades. The Nepali Army personnel's selfless sacrifice, institutional drive and integrity have made constructions projects cost effective for the Nepal Government and planners. Effectiveness of coordination between the Nepali Army and domestic civil agencies is critical both to improve Nepal's disaster response capabilities and to address Nepal's key areas of vulnerability. To promote that cooperation, specific measures can be taken, including but not limited to (1) conducting applied research, (2) helping to develop enhanced capacity and procedures, and (3) supporting strategic thinking and dialogue (Manandhar et.al, 2017).

\section{Nature conservation}

With a mission to protect endangered species, plants and the natural heritage, the Nepali Army has protected 12 out of the 22 forests under protection ever since 1975 (Nepali Army. 2019). Among them, 12 Battalions and Independent Companies with some 6,778 troops protect forest areas measuring some 9,767 sq $\mathrm{km}$. The impact of the mobilization of the Army is visible in the rhino census in Chitwan National Park. With the Army's efforts to protect the Chitwan National Park, backing the Rhino project, the 1994 census estimated about 466 individuals and this figure increased further to 544 individuals in 2000. The Department credits anti-poaching operations for the rapid rise in the numbers. However, the demands of internal security duties constrained the conservation efforts of the Nepali Army. As a result, the number of rhinos in Chitwan National Park fell to 372 individuals according to the census of 2005 . With the improvement in the internal security and consequent enhanced conservation efforts of the Army, the rhino population has steadily increased to 446. 
Preservation of natural heritage is one of the responsibilities given to the Nepali Army by Constitution of Nepal 2015 and National Security Policy 2016.

\section{Disaster management}

The Nepali Army plays a vital role in ensuring emergency assistance to needy people all over the country, a serious undertaking that has become even more important in the present context. The primary roles of the Nepali Army in disaster relief include search and rescue missions, medical assistance and evacuation, air rescue and mass evacuation and flood control. The Nepali Army is committed to support, in every possible manner, the efforts of the Nepalese Government in establishing Nepal as a 'Disaster Resilient Community.' Recently, in response to the massive earthquake, the Nepali government, Nepali Army, and civil society mobilized all the resources in support to survivors, joined by an outpouring of international assistance (Manandhar et.al, 2017). The major incidents in which the Nepali Army has served the people as a part of Disaster Management includes:

In 1934 AD, a devastating earthquake hit Nepal. The Nepali Army helped evacuate, and temporarily house thousands of people.

> The Nepali Army saved Singha Darbar when this historical palace was on a huge fire in 1971 AD.

An earthquake measuring 6.6 Richter scale hit Nepal on 21 August 1988 leaving 722 dead, 1421 seriously wounded and 11000 injured. The Nepali Army launched rescue and reconstruction operations, evacuating people, arranging first aids and relief materials.
> The 1993 torrential rainfall affected many of the districts, including Taplejung, Panchthar, Sindhuli, Sarlahi and Rautahat. The Nepali Army mobilized its troops to evacuate 3842 severely affected peopleand arranged medical treatments to 201 people on the spot.

$>$ The Nepali Army pulled off a breathtaking aerial rescue operation on 15 May 1995. A helicopter evacuated an American citizen, Sirbon B of the Swedish Everest Expedition and Makalu Gab of the Chinese Taipei Everest Expedition from an altitude of 19200 feet.

An aircraft with 12 people aboard crashed on 25 December 1999 in Makwanpur. The Nepali Army personnel recovered the dead bodies with supports of the military helicopters In 2007, a heavy rainfall resulted in a wide spread floods and landslides in Taplejung, Jhapa, Bhojpur, Saptari, Mahottari, Dhanusa, Kathmandu, Gorkha, Kaski, Syangja and Parbat. The Army ground and air assets consisting of 2885 personnel provided medical treatments to 10,000 people while rescuing them.

$>$ In August 2008, the Kosi River eroded the Eastern dyke near Kusaha and spilled over to change its course of flow where the NA rescued 15,060 persons from the inundated areas.

An earthquake with a magnitude of 7.8 Richter scale struck Nepal with its epicenter on Barpak, Gorkha on 15 April 2015. Also known as the Gorkha earthquake, a magnitude 7.3 aftershock hit Nepal, causing massive destruction of infrastructures, including schools, 
health centers, power systems, roads and bridges. The Nepali Army mobilized all of its units in 14 affected districts to rescue victims, arrange logistics and reconstruct the infrastructures. Besides, the Nepali Army personnel collaborated with international volunteers and representatives in rescue operations and necessary aids distribution.

\section{Rehabilitation center}

During the Maoist Insurgency period (1996 to 2006), the internal conflict took away thousands of lives while leaving thousands disabled. A comprehensive nationwide rehabilitation program was required in Nepal with physical rehabilitation, psychological rehabilitation, vocational rehabilitation and social awareness programs. Realizing such a need of the nation, the Nepali Army established a national rehabilitation center with supports from the Government of Nepal. This center primarily aims at operating Surveillance Team, Physiotherapy unit, Artificial limb and appliance workshop, Psychotherapy unit, Paraplegic home, General ward-50 bedded (For amputees coming for prosthesis, disabled those need physiotherapy and orthosis) and Vocational training center for various trade groups. The Nepali Army has provided 4.02 acre of land in Chhauni (valued at Rs 256 million). Till date, the Government has allocated Rs 30 million for construction of building and Rs 2 million for office furnishing and air conditioning of the physiotherapy hall and has committed further 22 million rupees for establishment of a physiotherapy unit and the necessary furniture (Nepali Army, 2019).

The Nepali Army has always been committed towards safeguarding the national unity, independence, territorial integrity and sovereignty of Nepal. Right from its establishment, NA has fulfilled its responsibilities and accountabilitiesin themost commendable manner. Its professionalism has been exhibited in the countless battles it fought during the Unification Campaign in eighteenth century, in safeguarding national sovereignty and maintaining peace during insurgencies at different times over centuries. Army also has proudly represented Nepal in the UN-led International Peace Keeping Missions around the globe since 1958 and remains the fifth largest contributor of human resource globally (Rayamajhi, 2019a).

\section{Conclusion}

The NA is engaged in safeguarding territorial integrity; constructing roads; protecting parks and reserves; responding to disasterrelated crises (rescue and recovery); UN peacekeeping operations; the security of V/VIPs; and the protection of crucial areas such as airports, banks and telephone towers. However, a debate is needed on whether to redefine, reorient, combine, modify or reduce the existing tasks (e.g. deciding whether to engage the army in nature conservation or in development work). Further, provisions on redefining the size of and attributing exclusive characteristics to the NA are mentioned in the interim constitution (Upreti \& Vanhoutte, 2009).

Hence, we can conclude that NA, along with the national security has been expanding its roles in sectors like education, health and recreation with the sole interest of serving the people. Keeping domestic contribution aside, the Nepali Army also has represented Nepal in the UN-led International Peace Keeping Missions around the globe. Its devotion to duty and excellence in executing 
its responsibility has been widely acclaimed. The (NA) has stood firm in its resolve to maintain stability and relentlessly supported the transformation and development of Nepal from 'nation formation' to 'nation building'. While our country has seen a lot of transformation in our journey from the monarchy to federalism, the Army's place and role have always remained respectable and stable. Nepali Army has been utilizing its trained manpower and resources in support of national progress for many decades.

\section{References}

Bhattrai, U. (2017). Political settlement: Nepali Army's role. Retrieved on December 22, 2019, from https://thehimalayantimes. com/opinion/political-settlement-nepalarmys-role/

Dhungana, S. K. (2007). Security sector reform and peacebuilding in Nepal: A critical reflection. Journal of Peacebuilding \& Development, 3(2), 70-78. doi:10.1080/15423 166.2007.360918411040

Hamal, L. B. (1995). Military history of Nepal. Sharda Pustak Mandir.

Manandhar, M. D., Varughese, G., Howitt, A. M., \& Kelly, E. (2017). Disaster preparedness and response during political transition in Nepal: Assessing civil and military roles in the aftermath of the 2015 earthquakes, 8-11.

Nepal Army. (2019). Nepali Army. Retrieved on December 25, 2019, from https://www. nepalarmy.mil.np/page/bpd

Nepalese Army. (n.d.). Nepalese Army and disaster management. Retrieved from https://www.nepalarmy.mil. np/upload/publications/special/english_part1. pdf on 2019.
Nepali Army (2019). Retrieved from https://www. nepalarmy.mil.np/page/history on November 11, 2019.

Poudel, K. (2016). Nepal Army by people's side. Retrieved from https://www.spotlightnepal. com/2016/03/04/nepal-army-by-peoplesside/ on December 26, 2019.

Rayamajhi, P. (2019, March 18). Nepali Army in nation building: Quality leadership is the key. Retrieved from https://thehimalayantimes. com/opinion/nepali-army-in-nation-buildingquality-leadership-is-the-key/ on December 24, 2019.

Rayamajhi, P. (2019a, March 18). Nepali Army in nation building: Quality leadership is the key. Retrieved from https://thehimalayantimes. com/opinion/nepali-army-in-nation-buildingquality-leadership-is-the-key/ December 24, 2019.

Thapa, P. C. (2019, February 9). Civil military relation: In present socio political environment of Nepal. Retrieved from https://www. spotlightnepal.com/2019/02/09/civil-militaryrelation-present-socio-political-environmentnepal/ on January 11, 2020.

The constitution of Nepal 2015 (CoN) s.4.1 (NPL)

The constitution of Nepal 2015 (CoN) s.5.1 (NPL)

Upreti, B. R., \& Vanhoutte, P. (2009). Security sector reform in Nepal: Challenges and opportunities. Security Sector Reform in Challenging Environments. Geneva: LIT Verlag, 165-187. 